\title{
A Discussion on the Socialist Deliberative Democracy with Chinese Characteristics
}

\author{
Yonghong Zhang ${ }^{1}$ \\ ${ }^{1}$ School of Marxism, Research Center for Marxist Theory, Southwest University, Chongqing, China \\ Correspondence: Yonghong Zhang, School of Marxism, Research Center for Marxist Theory, Southwest University, \\ Chongqing 400715, China. Tel: 86-138-8336-0756. E-mail: zyyhhh867@sohu.com
}

This paper is supported by the Fundamental Research Funds for the Central Universities "A Comparative Study of Democratic Socialism and Socialism with Chinese Characteristics" (SWU1009034).

Received: July 8, 2013 Accepted: August 9, 2013 Online Published: August 12, 2013

doi:10.5430/sass.v1n1p1 URL: http://dx.doi.org/10.5430/sass.v1n1p1

\begin{abstract}
The socialist deliberative democracy highlighted in the Eighteenth National Congress of the Communist Party of China has distinctive characteristics and is of great significance because it embodies the universality of socialist democracy, and is helpful to the orderly political participation of the people and the correct leadership of the Communist Party of China. To better adhere to and improve the socialist deliberative democracy with Chinese characteristics, a relaxed and stable, harmonious political environment should be maintained, the institutionalization and standardization construction should be constantly made, the combination of electoral democracy and deliberative democracy should be actively promoted, and the realization form of deliberative democracy at the grass-roots level should be radically innovated.
\end{abstract}

Keywords: socialist deliberative democracy with Chinese characteristics, significance, improvement

\section{Introduction}

Since the 1980s, there has been a surge of research into the deliberative democracy theory in the western academia. Scholars from different countries and with different academic backgrounds such as Habermas, Rawls, Giddens and Miller have all engrossed in exploring the intrinsic clue of this new theory. Besides, deliberative democracy theory research has gone beyond the limitation of philosophical thinking and theoretical research, and associated further and more commonly with political practice. With the growing tendency of China's reform and opening up, the social structure, economic composition in China has undergone a great change, giving birth to many new social strata and social groups. Differences of the social ranks, interests and political aspirations between different social groups are obvious. In this case, Chinese scholars have been constantly doing in-depth study on how to maintain an organic interaction and mutual adaptation between the centralized system with the Communist Party of China as the core and the increasingly diversified social structure. Some scholars advocate that the deliberative democracy should be built into the democratic political construction with Chinese characteristics, which is supposed to be able to further enrich and make perfect the socialist democratic politics in China, and meanwhile push forward the deliberative democracy theory itself. Against this background, practices of socialist deliberative democracy in China have been continuing to develop. The Eighteenth National Congress of the Communist Party of China, for the first time, proposes and systematically discusses the question of how to have a sound system of socialist deliberative democracy, which, from one side, reflects the practical and theoretical innovation of the Communist Party of China in socialist democracy. To know this system well, we need to clarify the following questions: What are the main characteristics of the Chinese socialist deliberative democracy? What is the significance of the socialist deliberative democracy? And how to adhere to and improve the socialist deliberative democracy with Chinese characteristics?

\section{The Chinese Deliberative Democracy Has Distinctive Chinese Characteristics}

2.1 The Chinese Deliberative Democracy Has the Marxist Theory of Multi-party Cooperation, the United Front Theory and the People's Democratic Theory as its Cornerstone

The theoretical basis of the deliberative democracy with Chinese characteristics is the Marxist theory of multi-party 
cooperation, the united front theory and the people's democratic theory, which is the greatest difference between the Chinese deliberative democracy and the western deliberative democracy. The formation and development of the deliberative democracy with Chinese characteristics is an inheritance and innovation of the Marxist theory of multi-party cooperation, the united front theory and the people's democratic theory. The theory of multi-party cooperation and the united front theory served as a magic key to China's successful revolution and have contributed to its construction afterwards. During the revolutionary period, the negotiation way was used to help join social forces and isolate the enemy, thus achieving the victory of the revolution. During the construction period, due to the complexity and difficulty of socialist construction, the negotiation way has also been needed to pool different ideas and carry out the economic construction. The united front theory argues that representatives of each group and people should participate institutionally in political consultation in public affairs, which is of great help for social conflicts to come into the channel of institutionalization, and avoid the intensification of social conflicts and unpredictable social crises.

2.2 The Chinese Deliberative Democracy Has Multi-party Cooperation and Political Consultative System under the Leadership of the CPC as its Platform

The system foundation of the Chinese deliberative democracy is the multi-party cooperation and political consultative system under the leadership of $\mathrm{CPC}$, which, on the one hand, fundamentally guarantee the healthy development of the Chinese deliberative democracy system, and on the other, has become one of the remarkable features of China's socialist democratic politics. Though the Chinese People's Political Consultative Conference (CPPCC) is not an organ of state power, political negotiation, political participation and democratic supervision are the main channels to implementing the deliberative democracy in China's political life.Using this platform, all democratic parties, non-party people can not only participate in the state power, state affair management as well as the formulation and implementation of policies, laws and regulations, but also can investigate and study the important issues in relation to the people's vital interests and put forward constructive suggestions and comments to the Party and state organs.This platform can fully satisfy the people's needs to participate in state management and meet their wishes to become real masters of the country. Besides, the multi-party cooperation and political consultative system under the leadership of CPC provides a platform for democratic supervision, and become an important indication of the deliberative democracy with Chinese characteristics.

\subsection{The Chinese Deliberative Democracy Has the Principle of Democratic Centralism as its Basis}

According to the democratic centralism, which is based on Marxist epistemology and the mass line, the Chinese deliberative democracy combines democratic consultation with majority voting and perfectly reflects the dialectical unity of democracy and centralization. The Communist Party of China and the democratic parties thoroughly air different views around common goals, and then, through a certain centralization, form a consensus on those which meet actual requirements. In this process, it's required that the minority be subordinate to the majority, the lower level subordinate to the higher level, and individuals follow the interests of the group.All the country's major issues should be discussed and decided in accordance with the principle of majority rule. From the perspective of operation mechanism, the democratic centralism guarantees the sound development of Chinese deliberative democracy and embodies the dialectical unification of democratic consultation and scientific decision-making.

\section{Upholding the Deliberative Democracy Is of Great Significance for Promoting the Development of Socialist Democratic Politics}

It is the essential requirement and intrinsic character of socialism for people to be masters of the country. In China, a socialist country, the state system-the people's democratic dictatorship, and the system of political power-the system of people's congress, are all concentrated reflection of the people as masters of the country. Therefore, ensuring the position of the people as masters of the country is the foundation of building socialism with Chinese characteristics. The deliberative democracy practice in China embodies people's basic interests, and fundamentally guarantees people's democratic rights to be masters of their own affairs.

\subsection{The Deliberative Democracy Embodies the Universality of Socialist Democracy}

The socialist deliberative democracy with Chinese characteristics is a socialist democracy reflecting the will of the masses. China is a socialist country based on public ownership of the means of production, in which the basic means of production are owned by all the working people and the working people share the same fundamental interests.On the basis of this consistency, the specific interests of different classes are not completely the same, and all democratic parties respectively represent specific interests of different classes. Through the practice of socialist deliberative democracy with Chinese characteristics can we not only ensure the realization of all working people's fundamental 
interests, but reflect the special requirements of different classes. First of all, the main body of deliberative democracy is very extensive, including different parties, groups and people from all walks of life, which encourages the free airing of views and reflects concentratively views and requirements of various social groups, thus maximizing the democratic rights of the broad masses. In addition, the content of the deliberative democracy is also very comprehensive, relating to economic, political, cultural affairs and other aspects. Major issues closely related with public interests all need widespread and full coordination.

\subsection{The Deliberative Democracy Is Conducive to Orderly Political Participation of the People from All Walks of Life}

As is mentioned above, with continuous development of reform and opening up to the outside world and market economy, unprecedented changes have taken place in people's interests in China. Major changes in social structure, economic elements have produced and are producing many new social strata and social groups. Differences of social status, interest requirements and political aspirations between different social groups are quite obvious. It's from this very basic national condition that the Communist Party of China rallyes strengths of all the parties and classes and groups from all walks of life, promotes understanding, broadens the channels for expression of people's interests, by deliberative democracy-a new form of democracy. This is not only beneficial to the report of the feelings of the common people to the higher authorities, but also facilitates the transmission of orders from above, which, assuredly, helps put into practice the decisions expressing the will of the people, and ensure that people truly achieve their self-determination rights.

\subsection{The Deliberative Democracy Ensures the Correct Leadership of the Communist Party of China}

The leadership of the Communist Party of China is mainly a political one, but what the Party needs to deal with nowadays includes all major issues with modernization construction as the core. Therefore, it can enrich and improve the leadership of the Communist Party if it is adept at absorbing all the favorable elements from both the Party and non-party groups. In addition, the Communist Party of China has an urgent need for direct supervision by all sectors of the society to overcome its own corruption. After coming to power, the Communist Party of China's status has changed, which, on the one hand,is beneficial to the construction of the ruling party, but on the other, makes the party members and cadres faced with the temptation of power. Years of ruling experience show that the external supervision supplemented by all sectors of the society can be more effective to prevent and stop the corruption within the Communist Party, and ensure the correct leadership of the Communist Party of China.

\section{We Need to Adhere to and Improve the Socialist Deliberative Democracy with Chinese Characteristics}

Any form of democracy has a process of constant construction, development and improvement. With the deepening of the reform and opening up and the development of socialist market economy, characteristics of social life-varied, diverse and changeable-are more prominent, political participation consciousness among people has been constantly improving, and wishes people express their interests have been growing, which demands that we uphold and improve the deliberative democracy, expand orderly political participation, develop socialist democratic politics and build socialist political civilization still further, so to make our society more harmonious and vibrant.

4.1 We Should Maintain a Relaxed and Stable, Harmonious Political Environment to Better Adhere to and Improve the Deliberative Democracy

The most obvious feature of the deliberative democracy is democratic consultation, equal discussion of official businesses and a consensus through consultation between the Communist Party of China and various aspects of the society. Only in a democratic, harmonious, comfortable and active atmosphere, can the deliberative democracy give full play to its unique advantage and function, thus truly becoming an important way to reflecting the condition of the people, absorbing public opinion and concentrating intelligence. To adhere to and make perfect our country's form of deliberative democracy, it's necessary to vigorously carry forward the democratic style of work, create a comfortable environment and advocate pragmatic attitude to make each party and all the people from all walks of life dare to put forward different views, so to create a political situation in which we have both centralism and democracy, both discipline and freedom, both unity of will and personal ease of mind and liveliness.

4.2 We Should Constantly Make the Institutionalization and Standardization Construction to Better Adhere to and Improve the Deliberative Democracy

Effective political consultation of the Communist Party with the eight democratic parties is a concrete manifestation of upholding the principle of "long-term coexistence, mutual supervision, treating each other with all sincerity and sharing weal and woe". In order to give full play to the role of political consultation, system construction must be further strengthened. We need to constantly develop and improve such basic political systems as the people's congress system and the Chinese people's Political Consultative Conference System to lay a solid foundation for the 
development of the deliberative democracy.We need to turn the views of the Party into the will of the state through statutory procedures and turn them into social consensus through political negotiation. We need to establish a good interactive relationship between National People's Congress and the society and give full play to people's function governing state and social affairs, and also strengthen the institutionalization, standardization and routinization of political consultation. In the new period, in order to adapt to the actual situation of economic and social development and the profound change of social classes, we also need to diligently follow the 16-character principle, promote the work of the Chinese people's political consultative conference and gradually incorporate it into the legal track. For some new forms of deliberative democracy in China, such as auditing system and hearing system,we need to further improve and develop them to build consultation mechanisms between parties and between the government and mass organizations, and to make this negotiation really become "an important part of the scientific and democratic decision-making" of the Communist Party of China and the government.

4.3 We Should Actively Promote the Combination of Electoral Democracy and Deliberative Democracy to Better Adhere to and Improve the Deliberative Democracy

That people are masters of the country is the essence of the socialist democracy. In today's China, the people's congress system is the political organizational form for guaranteeing that the people decide their own destiny.To develope the socialist democracy needs constant improvement of the people's congress system. The socialist China advocates an organic combination of electoral democracy and deliberative democracy, which, at the system level, is the mutual integration and complementary of people's congress system and the people's political consultative conference system. The political effect would be great and profound if we could combine the two democratic forms nicely. The People's congress system mainly embodies the electoral democracy and the people delegate their power to representatives through direct or indirect elections, while the people's political consultative conference system mainly embodies the deliberative democracy,in which CPPCC members from all walks of life could fully express their will and equally participate in political consultation. To comprehensively display opinions from all sectors of society through the people's congress system requires the assistance of deliberative democracy. Delegates of National People's Congress establish communication and consultation mechanisms with the voters through close ties with the masses to ensure the scientific nature and operability of decision-making on the basis of equal discussion and full consultation. To this end, we demand that the democratic parties and independents have appropriate proportions in the National People's Congress and be given supervision rights. We can also set up benign interactive relationship between the National People's Congress and the society and constantly broaden the channel of citizen participation in political consultation through the improvement of the hearing system, representative reception day system, etc.

4.4 We Should Radically Innovate the Realization form of Deliberative Democracy at the Grass-roots Level to Better Adhere to and Improve the Deliberative Democracy

Democracy at the grassroots level and mass autonomy is another form of the socialist deliberative democracy with Chinese characteristics.Mass autonomy in the socialist society is not only localized, but universal.Due to different characteristics of different basic units, the autonomous forms are varied, so we should establish and improve different forms of grass-roots self-government organizations based on the features of mode of production and the way people act in different areas. This is a demand for constructing socialist democracy and developing socialism. First, we need to further promote the villager autonomy in rural areas and improve the implementation form of it. At this moment,to establish scientific rules of democracy and democratic process, which is of great help to make the rural democratic construction move gradually in the direction of institutionalization and truly make village affairs public,is the main task. Since the reform and opening up to the outside world, there appear a lot of innovative forms of democracy at the grassroots level across the country, such as democratic talkfest created by Wenling, Taizhou city, Zhejiang province. The democratic talkfest is a creative development of the political practice of local governments in China in recent years and an important breakthrough in the construction of democracy at the grassroots level. Second, the grassroots autonomy is an arduous and long-term task. In the city, we must pay attention to the role of neighborhood committees and proprietor committees to realize the democratization of community management. The modern information communication is indispensable to deliberative democratic politics, and the positive role of the internet in promoting the deliberative democracy construction in communities should not be ignored. With the advantages of equality and openness, community network provides a more convenient platform for giving publicity to the policy of the party and government, as well as expressing opinions for citizens. Third, we need to put into practice and strengthen the democratic management of enterprises-make full use of the right-safeguarding function of the workers' congress and make efforts to guarantee the legitimate rights and interests of the masses of workers-to achieve social justice and promote the comprehensive and harmonious development. 


\section{Discussion}

Democracy is the core value and basic principle of modern society. Due to a long history of semi-colonial and semi-feudal society and an immature civil society, China's socialist democracy hasn't been fully displayed, which determines that the socialist democracy construction in China is still in the initial and primary stage. But, we have already built up a new democratic form in human history and ensured the position of the people as masters of the country theoretically and constitutionally.Though we have to admit that our democratic channel is not unobstructed, and that the form of democracy is not so diverse and the democratic process is not well standardized, institutionalized and legalized, the construction of our deliberative democracy at the grassroots level has accumulated a lot of good experience. The democratic theories and practices of the west have some reference for China's socialist democracy construction, but they couldn't be copied entirely. Only a reference based on the reasonable analysis, combined with national conditions, could be conducive to the construction of the socialist democracy in China. The construction of socialist democracy is a very complex and systematic project and will not happen overnight, so it needs to be constantly explored under the leadership of the Party. We firmly believe that under the joint exploration of people of all ethnic groups all over China, we shall assuredly succeed in charting out a way for the socialist democratic development suitable for China's national conditions and make a greater contribution to human society.

\section{Conclusion}

Deliberative democracy is one of the main forms of Chinese socialist democracy and an important embodiment of the Chinese people as masters of the country. As an important supplementary form of electoral democracy, deliberative democracy is an outcome of the combination of the Marxist united front theory, theory of socialist democratic politics with the Chinese concrete practices. From the practice point of view, The value concept and practical application of the socialist deliberative democracy with Chinese characteristics, which has People's Political Consultative Conference as its platform, vividly show the characteristics and advantages of the Chinese deliberative democracy, but, to keep and steadily improve these advantages, it's necessary to have this democracy constantly adapt to actual requirements of the development of Chinese society.

\section{References}

Dryzek, John S. (2000). Deliberative democracy and beyond: Liberals, critics, contestations. New York: Oxford University Press, Inc.

Gao, Jian, \& Tong, Dezhi. (2010). Deliberative democracy. Tianjin: Tianjin People's Publishing House.

Habermas, Jurgen. (1998). Between facts and norms: Contributions to a discourse theory of law and democracy. Cambridge, Mass.: MIT Press.

Hu, Jintao. A report delivered at the 18th National Congress of the Communist Party of China on Nov. 8, 2012.

Mishra, Ramesh. (1990). The welfare state in capitalist society: Policies of retrenchment and maintenance in Europe, North America and Australia. Toronto: University of Toronto Press.

Rawls, John. (2005). Political liberalism. New York: Columbia University Press.

Selected works of Deng Xiaoping (Vol. 2). (1994). Beijing: People's Publishing House.

Sun, Cunliang. (2009). Study of contemporary China's democratic consultation. Beijing: China Social Press. 